\title{
Monoraphidium and Ankistrodesmus (Chlorophyceae, Chlorophyta) from Pantanal dos Marimbus, Chapada Diamantina, Bahia State, Brazil
}

\author{
Geraldo José Peixoto Ramos ${ }^{1,2,4}$, Carlos Eduardo de Mattos Bicudo ${ }^{3}$, Aristóteles Góes Neto $^{2}$ and \\ Carlos Wallace do Nascimento Moura ${ }^{2}$
}

Received: 17.08.2011; accepted: 18.07.2012

\begin{abstract}
Monoraphidium and Ankistrodesmus (Chlorophyceae, Chlorophyta) from Pantanal dos Marimbus, Chapada Diamantina, Bahia State, Brazil).This study aimed to identify taxa belonging to the genera Monoraphidium and Ankistrodesmus (Chlorophyceae, Chlorophyta) in two wetland areas of Pantanal dos Marimbus (Baiano and Remanso) in the Marimbus-Iraquara Environmental Protection Area, Bahia State, Brazil, and contribute to the knowledge of Chlorophyceae of Bahia State and Brazil. The materials studied, which were of periphytic and metaphytic origin, came from 64 samples collected in April and June 2011. We identified 18 taxa, 13 from Monoraphidium and five from Ankistrodesmus. Eight taxa were additions to the continental microalgae flora of Northeastern Brazil. Two taxa rarely found in Brazil were collected during the study: Monoraphidium dybowskii and M. litorale.
\end{abstract}

Key words: algae, biodiversity, Chlorococcales

RESUMO - (Monoraphidium e Ankistrodesmus (Chlorophyceae, Chlorophyta) do Pantanal dos Marimbus, Chapada Diamantina, BA, Brasil). Este estudo teve por objetivo inventariar os táxons de Monoraphidium e Ankistrodesmus (Chlorophyceae, Chlorophyta) de duas áreas alagáveis do Pantanal dos Marimbus (Baiano e Remanso), Área de Proteção Ambiental Marimbus-Iraquara, Bahia e contribui para o conhecimento das Chlorophyceae do Estado da Bahia e Brasil. Os materiais estudados, de origem perifítica e metafítica, provieram de 64 amostras coletadas em abril e junho de 2011. Foram identificados 18 táxons, 13 de Monoraphidium e cinco de Ankistrodesmus, dos quais oito são adições à flora de microalgas continentais da região Nordeste. Dois táxons raramente encontrados no Brasil foram coletados durante este estudo: Monoraphidium dybowskii e M. litorale.

Palavras-chave: algas, biodiversidade, Chlorococcales

\section{Introduction}

The Pantanal dos Marimbus is considered one of the main ecosystems in Chapada Diamantina and corresponds to an extensive wetland area that is subject to periodic flooding, draining most of the region's rivers (Sema 2011). The Bahia State Government transformed this region into a protected area (Marimbus-Iraquara EPA) due to its rich biological diversity with Decree $\mathrm{n}^{\circ} 2216$ of June 14, 1993.

According to Taniguchi et al. (2005), despite the immense representation of wetlands in Brazil, knowledge regarding the algal communities in these aquatic systems is still scarce. Most phycological studies in these environments highlight the Chlorophyceae class as being the most common group (De-Lamonica-Freire \& Heckman 1996, De-Lamonica-Freire \& Sant'Anna 1993). This group generally stands out due to its extensive distribution, diversity, and species richness, in addition to being essential in ecological studies (Comas 1996).

The two genera Monoraphidium KomárkováLegnerová and Ankistrodesmus Corda are among those that deserve attention in the Chlorophyceae class.

1. Part of a Master's Dissertation from the First Author

2. Universidade Estadual de Feira de Santana, Programa de Pós-Graduação em Botânica, Av. Transnordestina, s/n, Novo Horizonte, 44036-900 Feira de Santana, Bahia, Brasil

3. Instituto de Botânica, Núcleo de Pesquisa em Ecologia, Av. Miguel Estéfano, 3687, 04301-902 São Paulo, SP, Brasil

4. Corresponding author: geraldojpr@gmail.com 
Both genera are commonly found in many continental tropical and temperate aquatic environments, primarily those with high nutrient content (Reynolds 1984). In addition, representatives of these genera are widely used in physiological studies due to their rapid growth rate in culture (Sipaúba-Tavares et al. 1999, El-Sheekh et al. 2003).

The knowledge of the Monoraphidium and Ankistrodesmus genera in Bahia State is scarce and currently restricted to studies by Menezes et al. (2012) and reports of ecological content by Fuentes et al. (2010) and Santana (2011), in which the species are represented only by listings. Taxonomic studies with descriptions and illustrations of these genera do not exist for Bahia State.

This study aimed to conduct a taxonomic inventory of the Monoraphidium and Ankistrodesmus genera at two areas in the Pantanal dos Marimbus (Remanso and Baiano), Chapada Diamantina, to contribute to the knowledge of Chlorophyceae of Bahia State and Brazil.

\section{Material and methods}

The Pantanal dos Marimbus corresponds to a flood plain formed by the confluence of the Santo Antônio, Utinga, and São José Rivers, covering the municipalities of Lençóis and Andaraí in Chapada Diamantina, Bahia State, Brazil. The Marimbus are subdivided in four areas (Remanso, Fazenda Velha, Ferreira and Baiano).

The study was conducted in two areas of the Pantanal dos Marimbus (Remanso and Baiano) (figure 1). The Marimbus do Remanso $\left(41^{\circ} 20^{\prime} \mathrm{W}\right.$, $\left.12^{\circ} 40^{\prime} \mathrm{S}\right)$, is located at the municipality of Lençóis and near the village of Remanso, and is characterized by calm waters (most zones) with $\mathrm{pH}$ 6.6-7.6 and average transparency $(2.1 \mathrm{~m})$. It is notable the influence of the Santo Antonio River in the dynamics of the environment, especially in the narrower parts, in which current flow is higher.

The Marimbus do Baiano $\left(41^{\circ} 18^{\prime} \mathrm{W}, 12^{\circ} 45^{\prime} \mathrm{S}\right)$, located in the municipality of Andaraí, consists of several interconnected lakes such as Lagoa do Baiano, Lagoa da Isca, Lagoa dos Paus and Olho D'Agua do Peri. These subdivisions are most used by local fishermen in the dry season, when the water regime of the Santo Antonio River is well below normal, and then there is no interconnection between them. Considering this subdivision, the samples of the present study, collected in Marimbus do Baiano, were concentrated in the Lagoa do Baiano. The area is characterized also by calm waters with $\mathrm{pH}$ 6.0-7.2 and average transparency $(0.9 \mathrm{~m})$. The Marimbus areas have several macrophytes such as Utricularia foliosa L., Cabomba haynesii Wiersema, Eichhornia azurea (Sw.) Kunth., Nymphaea ampla (Salisb.) DC, Salvinia auriculata Aubl. and Hydrocleys nymphoides (Humb. \& Bonpl. ex Willd.).

Sixty four samples of periphytic and metaphytic material studied were collected during April and June 2011 (beginning of the dry season) and came mainly from these macrophytes cited. All collections were made using standardized techniques for taxonomic studies of continental microalgae (Bicudo \& Menezes 2006).

The metric limits of the specimens were obtained using an ocular micrometer, and the photomicrographs were acquired with a digital camera coupled to an optical microscope. The species were identified based on the specialized literature; the classification system adopted follows Komárek \& Fott (1983).

Samples were preserved in Transeau solution follow Bicudo \& Menezes (2006), and incorporated in the liquid collection at the Herbarium of the Universidade Estadual de Feira de Santana (HUEFS).

\section{Results and discussion}

In the present study on Pantanal do Marimbus, 18 taxa, 13 from Monoraphidium Corda and five from Ankistrodesmus Komárková-Legnerová were identified:

Chlorophyta, Chlorellaceae

Ankistrodesmus Corda, Alman. Carlsbad, 8: 196. 1838

Cells in colonies, rarely solitary, forming clumps or loose to dense fascicles, parallel or sometimes spirally arranged around each other. Fusiform cells, longer than wide, may be straight, curved, or sigmoid, with gradually or abruptly tapered ends; smooth cell wall; parietal chloroplast without pyrenoids. Reproduction by 2-16 autospores, arranged in parallel within the mother cell, which are released after the breakup of the cell wall (Comas 1996).

Type species: Ankistrodesmus falcatus (Corda) Ralfs 1848. 


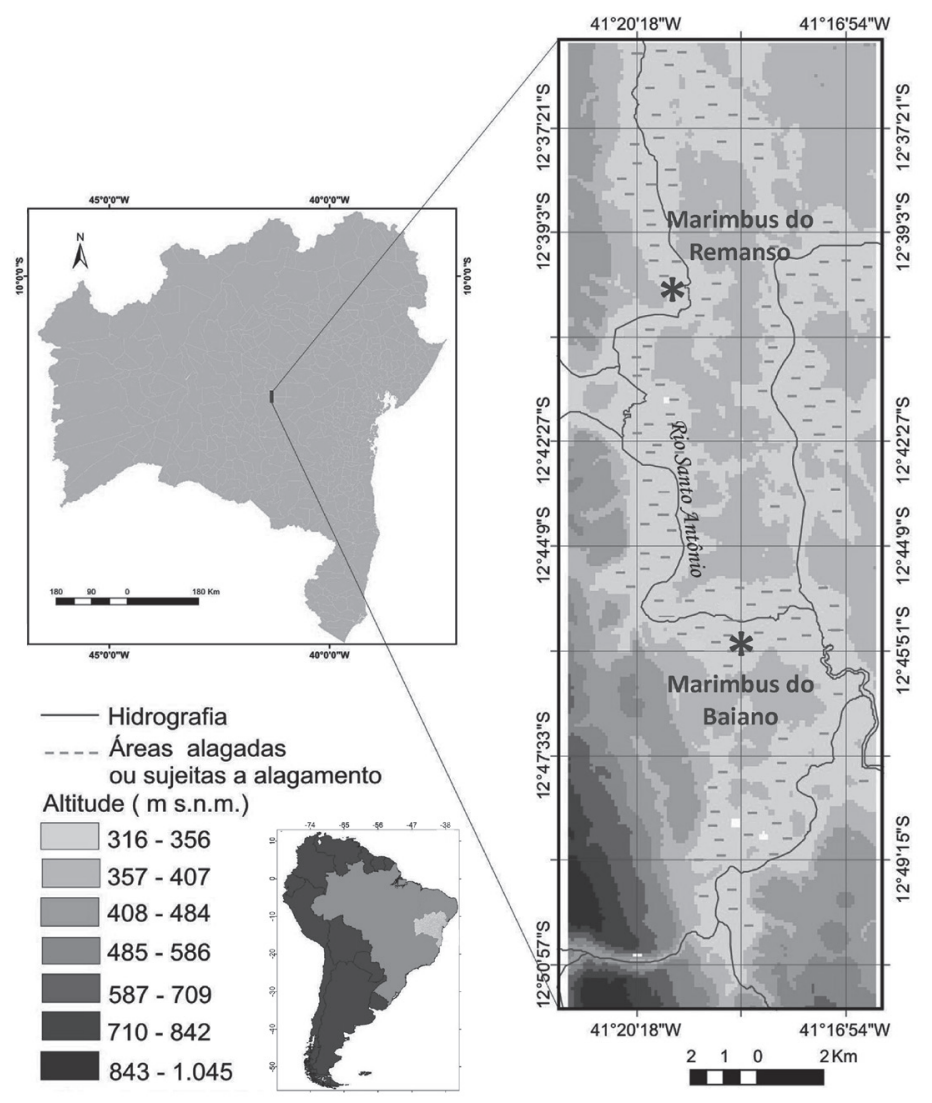

Figure 1. Localization of Pantanal dos Marimbus and the two sampled areas, Bahia State, Brazil (modified from França et al. 2011).

Key for identification of the species of Ankistrodesmus in the Pantanal dos Marimbus

1. Straight or falcate cells

2. Falcate cells joined by a convex medial region A. falcatus

2. Straight cells in a crucial or radial arrangement A. fusiformis

1. Curved, sigmoid, or helical cells

3. Colonies of up to 8 cells, twisted in a helical manner in the medial region

3. Colonies with more than 8 cells

4. Colonies with a maximum of 10 fusiform cells, sigmoidally curved in the medial region ... A. bernardii

4. Colonies with a minimum of 16 sigmoid or curved cells throughout their length

A. densus

Ankistrodesmus bernardii Komárek, Nova Hedwigia 37: 138, 176, pl. 25, fig. 65. 1983.

Figure 2a

Fasciculate colonies with approximately 8-10 fusiform cells, slightly sigmoidal curve on the medial region, 23-28 times longer than broad, joined and interwoven in the medial region of the colony, gradually tapered toward the apex; single, parietal chloroplast without pyrenoids. Cell dimensions: 42.5-58.5 $\mu \mathrm{m}$ in length, 1.5-2.5 $\mu \mathrm{m}$ in width.

Material examined: BRAZIL. BAHIA: Andaraí, Marimbus-Iraquara EPA, Marimbus do Baiano, 1-IV-2011 G.J.P. Ramos \& C.W.N. Moura s.n (HUEFS178326, HUEFS178327, HUEFS178328, HUEFS178329, HUEFS178330, HUEFS178332, HUEFS178335, HUEFS178336, HUEFS178339, HUEFS178342, HUEFS178343, HUEFS178344); 29-VI-2011, G.J.P. Ramos \& C.W.N. Moura s.n (HUEFS178362, HUEFS178365, HUEFS178366, HUEFS178373, HUEFS178376, HUEFS178377).

Geographic distribution in Brazil: Tocantins, Mato Grosso, Goiás, Espírito Santo, São Paulo, Rio de Janeiro, Paraná (Menezes et al. 2012) and Bahia (present study).

According to Komárek (1983), Ankistrodesmus bernardii usually forms colonies with many cells that are variable in length. This species is closely related to A. densus, which differs by having curved or sigmoid 

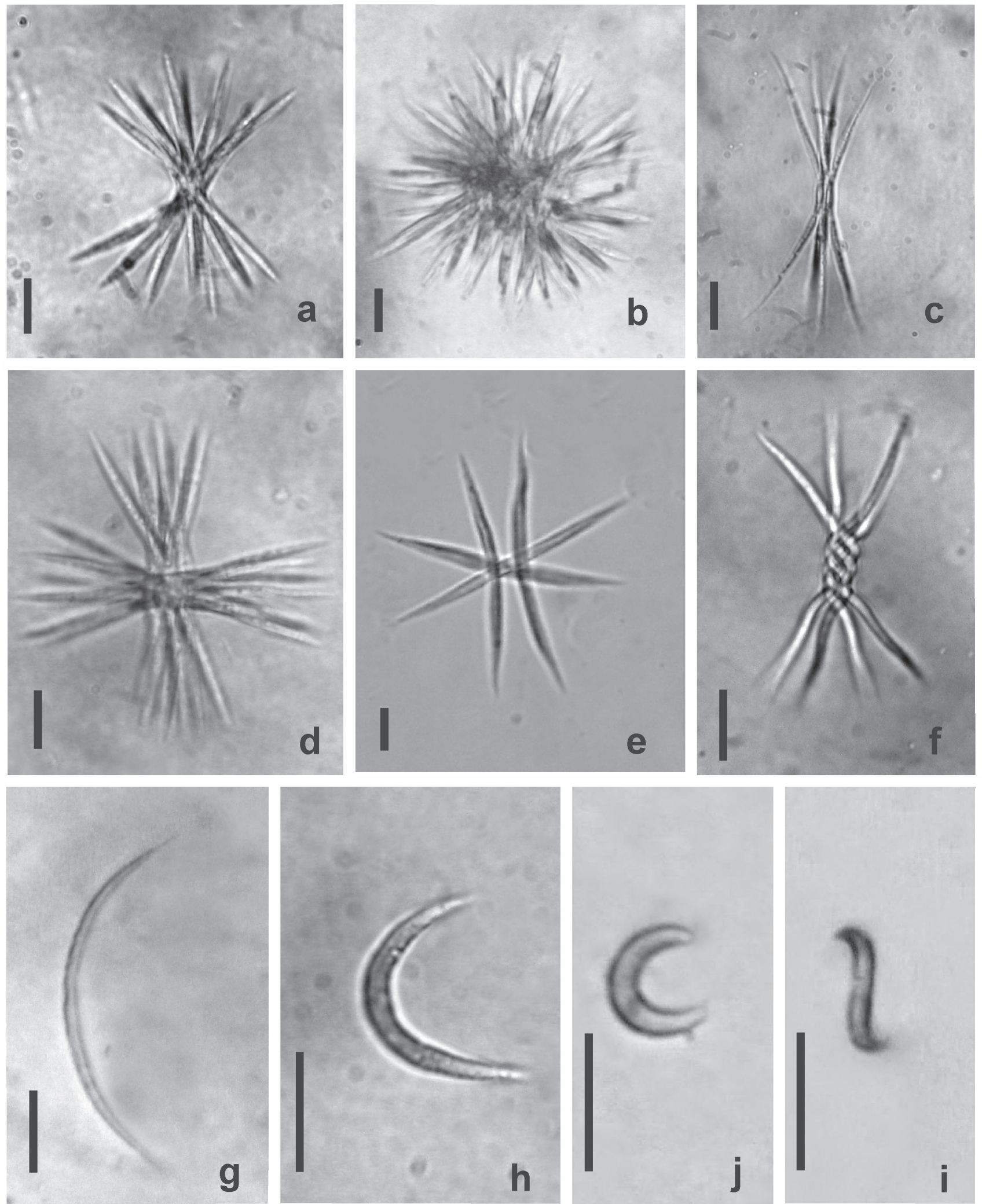

Figure 2. a. Ankistrodesmus bernardii; b. A. densus; c-d. A. falcatus; e. A. fusiformis; f. A. spiralis; g. Monoraphidium arcuatum; h. M. caribeum; i-j: M. circinale (Bars $=10 \mu \mathrm{m})$. 
cells throughout its length, in addition to having longer cells.

According to Komárek (1983) and Comas (1996), A bernardii is a tropical species that occurs in periphytic communities from meso-eutrophic aquatic environments.

The populations analyzed in the study area are in accordance to the descriptions and illustrations reported by Komárek \& Fott (1983), Comas (1996), and Nogueira \& Oliveira (2009).

This report constitutes the first citation of the species for Northeastern Brazil.

Ankistrodesmus densus Korshikov, Protococcinae: 300, fig. 262. 1953

Figure $2 b$

Fasciculate colonies with 16 or more densely grouped cells; long cells, 18-40 times longer than broad, fusiform, curved, or sigmoid throughout its length, gradually tapered towards the apex, superimposed on each other; single, parietal chloroplast without pyrenoids. Cell dimensions: $50-65 \mu \mathrm{m}$ in length, 1.25-3.5 $\mu \mathrm{m}$ in width.

Material examined: BRAZIL. BAHIA: Andaraí, Marimbus-Iraquara EPA, Marimbus do Baiano, 1-IV-2011, G.J.P. Ramos \& C.W.N. Moura s.n (HUEFS178325, HUEFS178326, HUEFS178327, HUEFS178328, HUEFS178329, HUEFS178330, HUEFS178331, HUEFS178332, HUEFS178333, HUEFS178334, HUEFS178335, HUEFS178336, HUEFS178338, HUEFS178340, HUEFS178342, HUEFS178343, HUEFS178344, HUEFS178345); 29-VI-2011, G.J.P. Ramos \& C.A. Ribeiro s.n (HUEFS178362, HUEFS178363, HUEFS178365, HUEFS178366, HUEFS178370, HUEFS178372, HUEFS178373, HUEFS178374, HUEFS178375, HUEFS 178378, HUEFS 178379); Lençóis, Marimbus-Iraquara EPA, Marimbus do Remanso, 2-IV-2011, G.J.P. Ramos \& C.W.N. Moura s.n (HUEFS178352, HUEFS178353, HUEFS178361).

Geographic distribution in Brazil: Amazonas, Tocantins, Goiás, Minas Gerais, São Paulo, Rio de Janeiro, Paraná (Menezes et al. 2012) and Bahia (present study).

The populations studied agreed with the descriptions and illustrations reported by Komárek \& Fott (1983) and Sant'Anna (1984); however, the analyzed cells are longer than those reported by Bortolini et al. (2010).
The taxon is likely cosmopolitan and is found in neutral or acidic waters (Comas 1996, John \& Tsarenko 2002).

This report constitutes the first citation of the species for Northeastern Brazil.

Ankistrodesmus falcatus (Corda) Ralfs, Brit Desm.,180, pl. 34, figs. a-c. $1848 \equiv$ Micrasterias falcata Corda, Alman Carlsbad 5: 206, pl. II, fig. 29. 1835.

Figures 2c-2d

Colonies with 1-4 fascicules of four cells arranged in an irregular manner; cells are long, fusiform, slightly curved, falcate, 26-30 times longer than broad, joined together by the convex medial region, gradually tapered towards the apex; single, parietal chloroplast without pyrenoids. Cell dimensions: $40-78.5 \mu \mathrm{m}$ in length, $1.5-2.5 \mu \mathrm{m}$ in width.

Material examined: BRAZIL. BAHIA. Andaraí, Marimbus-Iraquara EPA, Marimbus do Baiano, 1-IV-2011, G.J.P. Ramos \& C.W.N. Moura S.n (HUEFS178326, HUEFS178328, HUEFS178329, HUEF S178338, HUEFS178344), 29-VI-2011, G.J.P. Ramos \& C.A. Ribeiro s.n (HUEFS178362, HUEFS178371, HUEFS178372, HUEFS178375, HUEFS178377); Lençóis, Marimbus-Iraquara EPA, Marimbus do Remanso, 2-IV-2011, G.J.P. Ramos \& C.W.N. Moura s.n. (HUEFS178347, HUEFS178352, HUEFS178359); 30-VI-2011, G.J.P. Ramos \& C.A. Ribeiro s.n. (HUEFS178383, HUEFS178385, HUEFS178386, HUEFS178387, HUEFS178388, HUEFS178391, HUEFS178392, HUEFS178393).

Geographic distribution in Brazil: Roraima, Amazonas, Minas Gerais, Espírito Santo, São Paulo, Rio de Janeiro, Paraná, Santa Catarina (Menezes et al. 2012) and Bahia (present study).

According to Hindák (1984), when there is displacement of the two central cells of Ankistrodesmus falcatus forming angles close or equal to $90^{\circ}$, the colony has similar morphology to that of A. fusiformis; however, this species is distinguished by its smaller cell sizes.

The Ankistrodesmus falcatus populations examined in this study are consistent with the descriptions and illustrations reported by Komárek \& Fott (1983), Nogueira (1991), and Comas (1996), although the maximum metric limits recorded for specimens from Bahia State have been slightly higher than those found by these authors.

John \& Tsarenko (2002) and Comas (1996) consider A. falcatus cosmopolitan, common in 
calm and oligotrophic waters, and to occur in both planktonic and periphytic environments.

This report constitutes the first citation of the species for Northeastern Brazil.

Ankistrodesmus fusiformis Corda ex Korshikov, Protococcinae: 300, fig. 263. 1953

Figure 2e

Colonies of 2-4 (-8) cells, radially or crucially arranged; cells are elongated-fusiform, straight or slightly curved, 26-35 times longer than broad, gradually tapered and pointed apex; single, parietal chloroplast without pyrenoids. Cell dimensions: 27.5-60 $\mu \mathrm{m}$ in length, $1.25-2.5 \mu \mathrm{m}$ in width.

Material examined: BRAZIL. BAHIA: Andaraí, Marimbus-Iraquara EPA, Marimbus do Baiano, 1-IV-2011, G.J.P. Ramos \& C.W.N. Moura s.n (HUEFS178325, HUEFS178326, HUEFS178327, HUEFS 178329, HUEFS178330, HUEFS178331, HUEFS178332, HUEFS178336, HUEFS178337, HUEFS 178342, HUEFS178343); 29-VI-2011, G.J.P. Ramos \& C.A. Ribeiro S.n. (HUEFS178362, HUEFS 178363, HUEFS178366, HUEFS178368, HUEFS 178372, HUEFS178373, HUEFS178374, HUEFS178378, HUEFS178379); Lençóis, MarimbusIraquara EPA, Marimbus do Remanso, 2-IV-2011, G.J.P. Ramos \& C.W.N. Moura s.n. (HUEFS178346, HUEFS178352, HUEFS178353, HUEFS178359), 30-VI-2011, G.J.P. Ramos \& C.A. Ribeiro s.n (HUEFS178380, HUEFS178384, HUEFS178385, HUEFS 178388, HUEFS178390, HUEFS178391, HUEFS178392, HUEFS178393).

Geographic distribution in Brazil: Amapá, Amazonas, Tocantins, Goiás, Distrito Federal, Espírito Santo, São Paulo, Rio de Janeiro, Paraná, Rio Grande do Sul (Menezes et al. 2012) and Bahia (Fuentes et al. 2010, Santana 2011).

In the studied $A$. fusiformis populations, there were varied numbers of cells, predominantly in small, ephemeral colonies with 2-4 cells, although colonies with eight cells were found. In addition, there is a cell polymorphism, with cell shape being sometimes straight and sometimes slightly curved.

The material analyzed is consistent with the descriptions and illustrations by Komárek \& Fott (1983), Sant'Anna (1984), and Bortolini et al. (2010).

Ankistrodesmus fusiformis was previously cited for Bahia State by Fuentes et al. (2010) and Santana (2011) from analysed material from the Rio de Contas and Almada River, respectively. The authors did not provided comments or illustrations of the material studied. Therefore, we consider the present study to be the first time that the occurrence of the species was confirmed in Bahia State.

The taxon is likely cosmopolitan and is usually found in the plankton and periphyton of aquatic environments (Comas 1996, John \& Tsarenko 2002).

Ankistrodesmus spiralis (W.B.Turner) Lemmermann, Arch Hydrobiol U Planktonk, 4: 176. $1908 \equiv$ Rhaphidium spirale W.B.Turner, Alg Ind Orient, 156, pl. XX, fig. 26. 1893.

Figure $2 \mathrm{f}$

Colonies with a fascicle, composed of 2-8 fusiform cells, 20-26 times longer than broad, joined together and twisted in a helical manner in the medial region, tapered apices; single, parietal chloroplast without pyrenoids. Cell dimensions: $40-50 \mu \mathrm{m}$ in length, $1.5-2.5 \mu \mathrm{m}$ in width.

Material examined: BRAZIL. BAHIA: Andaraí, Marimbus-Iraquara EPA, Marimbus do Baiano, 1-IV-2011, G.J.P. Ramos \& C.W.N. Moura s.n. (HUEFS178327, HUEFS178329, HUEFS178333, HUEFS178341, HUEFS178342, HUEFS178344); 29-VI-2011, G.J.P. Ramos \& C.A. Ribeiro s.n. (HUEFS178372); Lençóis, Marimbus-Iraquara EPA, Marimbus do Remanso, 2-IV-2011, G.J.P. Ramos \& C.W.N. Moura s.n (HUEFS178347, HUEFS178352, HUEFS178359), 30-VI-2011, G.J.P. Ramos \& C.A. Ribeiro s.n (HUEFS178380, HUEFS178383, HUEFS178385, HUEFS178389, HUEFS178390, HUEFS178391, HUEFS178392, HUEFS178393, HUEFS178394).

Geographic distribution in Brazil: Paraíba, Goiás, Distrito Federal, Minas Gerais, São Paulo, Rio de Janeiro, Paraná (Menezes et al. 2012) and Bahia (present study).

Morphologically, Ankistrodesmus spiralis is similar to $A$. densus; however, this species is distinguished by having a colony with 16 or more cells, less torsion throughout the cell, and larger cell measurements (wider and longer cells).

The populations analyzed in the Pantanal dos Marimbus agreed with the descriptions and illustrations presented by Komárek \& Fott (1983), Hindák (1988), and Bortolini et al. (2010), although the cell dimensions shown by these latter authors were smaller than those found in the studied specimens.

According to John \& Tsarenko (2002), A. spiralis is cosmopolitan and is common in acidic aquatic environments. This report constitutes the first citation of the species for Bahia State. 
Monoraphidium Komárková-Legnerová, In Fott, Stud Phyc: 96. 1969.

Single cells, fusiform, cylindrical, longer than broad, straight, curved or sigmoid, sometimes spiral, gradually tapered towards the apex, which may be tapered or rounded; smooth cell wall; parietal chloroplast, without pyrenoids. Reproduction by 4-8 autospores, arranged in series within the mother cell, which are released after breaking up the wall of the mother cell into two parts (Comas 1996).

Type species: Monoraphidium griffithii (Berk.) Komárková-Legnerová 1969.

Artificial key for identify the species of Monoraphidium in the Pantanal dos Marimbus

1. Apices of the cells rounded

2. Cylindrical, straight, or slightly curved cells M. dybowskii

2. Reniform cells

3. Cells $9-12 \mu \mathrm{m}$ long M. minutum

3. Cells 4-6 $\mu \mathrm{m}$ long M. nanum

1. Apices of the cell tapered

4. Fusiform, straight, or slightly curved cells

5. Cells shorter than $30 \mu \mathrm{m}$

6. Straight cells M. litorale

6. Slightly curved cells

7. Tapered to finger-like apices, 25-28.5 $\mu \mathrm{m}$ long ..... M. pusillum

7. Needle-like apices, $12-20 \mu \mathrm{m}$ long M. tortile

5. Cells longer than $40 \mu \mathrm{m}$

8. Long needle-like apices, 50-105 $\mu \mathrm{m}$ long . M. kormakovae

8. Short spine apices, 45-58 $\mu \mathrm{m}$ long

4. Arched, sigmoid, or spiral cells M. griffithii

9. Arched cells

10. Cells up to $12 \mu \mathrm{m}$ long

10. Cells above $12 \mu \mathrm{m}$ long

11. Cells 30-45(-56) $\mu \mathrm{m}$ long M. arcuatum

11. Cells $12.5-18.75 \mu \mathrm{m}$ long ... M. caribeum 9. Sigmoid or spiral cells

12. Cells $7.5-12 \mu \mathrm{m}$ long

12. Cells 34-39 $\mu \mathrm{m}$ long M. contortum M. irregulare

Monoraphidium arcuatum (Korshikov) Hindák, Alg Stud 1: 25. $1970 \equiv$ Ankistrodesmus arcuatus Korshikov, Protococcineae, 296, fig. 297. 1953. Figure $2 \mathrm{~g}$

Cells solitary, arched or semi-circular, gradually narrowing to the ends with pointed apices; single parietal chloroplast, without pyrenoids. Cell dimensions: $30-45(-56) \mu \mathrm{m}$ in length, $1.5-2.5 \mu \mathrm{m}$ in width.

Material examined: BRAZIL. BAHIA: Andaraí, Marimbus-Iraquara EPA, Marimbus do Baiano, 1-IV-2011, G.J.P. Ramos \& C.W.N. Moura s.n. (HUEFS178326, HUEFS178327, HUEFS178328, HUEFS178329, HUEFS178332, HUEFS178341, HUEFS178342, HUEFS178343, HUEFS178344); 29-VI-2011, G.J.P. Ramos \& C.A. Ribeiro s.n (HUEFS178362, HUEFS178363, HUEFS178365, HUEFS178366, HUEFS178372, HUEFS178373, HUEFS178374, HUEFS178376, HUEFS178378); Lençóis, Marimbus-Iraquara EPA, Marimbus do Remanso, 2-IV-2011, G.J.P. Ramos \& C.W.N. Moura s.n. (HUEFS178347, HUEFS178351, HUEFS178352, HUEFS178353, HUEFS178354); 30-VI-2011, G.J.P. Ramos \& C.A. Ribeiro s.n (HUEFS178380, HUEFS178384, HUEFS178385, HUEFS178387, HUEFS178388, HUEFS178389, HUEFS178390, HUEFS178391, HUEFS178392, HUEFS178393, HUEFS178394).

Geographic distribution in Brazil: Amazonas, Tocantins, Rio Grande do Norte, Pernambuco, Goiás, Distrito Federal, Espírito Santo, São Paulo, Rio de Janeiro, Paraná (Menezes et al. 2012) and Bahia (Menezes et al. 2012, Fuentes et al. 2010).

Monoraphidium arcuatum is morphologically similar to $M$. indicum Hindák; however, this species differs by having larger cell dimensions and being generally more rounded and curved.

The studied populations corroborate with the descriptions, measurements, and illustrations reported by Komárek \& Fott (1983), Comas (1996), Nogueira (1999), and Bortolini et al. (2010).

Fuentes et al. (2010) \& Menezes et al. (2012) reported the occurrence of $M$. arcuatum in Bahia State. These authors did not describe or illustrate the morphology of the material studied. Due to the lack of factual information contained in these studies, the reports by Fuentes et al. and by Menezes et al. were discarded, and the present study is considered as a pioneer in Bahia State.

The taxon is likely cosmopolitan, occurring in the plankton and metaphyton (Komárek \& Fott 1983) or in the plankton and periphyton from eutrophic environments (Comas 1996).

Monoraphidium caribeum Hindák, Algol Stud 1:26, fig. 11. 1970.

Figure $2 \mathrm{~h}$ 
Cells solitary, arched in a semi-circle, slightly tapered at the ends; parietal chloroplast and without pyrenoids. Cell dimensions: $12.5-17.5 \mu \mathrm{m}$ in length, $1.5-2.5 \mu \mathrm{m}$ in width.

Material examined: BRAZIL. BAhIA: Andaraí, Marimbus-Iraquara EPA, Marimbus do Baiano, 1-IV-2011, G.J.P. Ramos \& C.W.N. Moura s.n. (HUEFS178344); 29-VI-2011, G.J.P. Ramos \& C.A. Ribeiro s.n. (HUEFS178364, HUEFS178372, HUEFS178373); Lençóis, Marimbus-Iraquara EPA, Marimbus do Remanso, 2-IV-2011, G.J.P. Ramos \& C.W.N. Moura s.n. (HUEFS178352); 30-VI-2011, G.J.P. Ramos \& C.A. Ribeiro s.n. (HUEFS178392).

Geographic distribution in Brazil: Amazonas, Rio de Janeiro, Paraná (Menezes et al. 2012) and Bahia (present study).

According to Comas (1996), Monoraphidium caribeum differs from $M$. arcuatum only by cell dimensions. In addition to these dimensions, it is possible to observe in the analyzed populations that cells of $M$. arcuatum have gradually tapered apices.

The material analyzed in the present study agreed with the descriptions and illustrations of specimens studied by Komárek \& Fott (1983), Comas (1996), and Nogueira (1999).

The species is cosmopolitan and is found primarily in the plankton and periphyton from eutrophic aquatic environments (Comas 1996).

This report constitutes the first citation of the species for Northeastern Brazil.

Monoraphidium circinale (Nygaard) Nygaard, Bot Tidsskr 73: 212. 1979 三 Monoraphidium capricornutum (Printz) Nygaard var. circinale Nygaard, K danske Vidensk Selsk Skr, 21(1): 60, fig. 14-29. 1977

Figures $2 \mathrm{i}-2 \mathrm{j}$

Cells solitary, fusiform, arched in semi-circles, in viewed sideways, are in the contour spherical; slightly tapered at the ends; single parietal chloroplast without pyrenoids. Cell dimensions: $4.5-10.5 \mu \mathrm{m}$ in length, $1.5-2 \mu \mathrm{m}$ in width.

Material examined: BRAZIL. BAHIA: Andaraí, Marimbus-Iraquara EPA, Marimbus do Baiano, 1-IV-2011, G.J.P. Ramos \& C.W.N. Moura s.n. (HUEFS178332, HUEFS178342, HUEFS178344); Lençóis, Marimbus-Iraquara EPA, Marimbus do Remanso, 2-IV-2011, G.J.P. Ramos \& C.W.N. Moura s.n. (HUEFS178352); 30-VI-2011, G.J.P. Ramos \& C.A. Ribeiro s.n. (HUEFS178390).
Geographic distribution in Brazil: Amazonas, Goiás, São Paulo, Rio de Janeiro, Paraná (Menezes et al. 2012) and Bahia (present study).

Morphologically, Monoraphidium circinale is similar to M. minutum; however, this species differs by having cylindrical poles and generally broader cells.

The specimens analyzed in the Pantanal dos Marimbus have slightly smaller cell measurements than those reported by Nogueira (1999) and Hindák (1988); however, they are consistent with the description and illustrations reported by Komárek \& Fott (1983).

According to Komárek \& Fott (1983), the species is usually found in the plankton, primarily in eutrophic and alkaline environments.

This report constitutes the first citation of this species for Northeastern Brazil.

Monoraphidium contortum (Thuret) KomárkováLegnerová, Stud Phycol:104, pl. 18, fig. 1-5. $1969 \equiv$ Ankistrodesmus contortus Thuret, Mem Soc Imper Sci Nat Cherbourg 4:158, pl. I, fig. 31. 1856. Figure $3 \mathrm{a}$

Cells solitary, irregularly curved, from sigmoid to spiral (1.0-1.5 turns), gradually tapered apices, pointed ends; single parietal chloroplast without pyrenoids. Cell dimensions: $7.5-12 \mu \mathrm{m}$ in length, $1.5-2 \mu \mathrm{m}$ in width.

Material examined: BRAZIL. BAHIA: Andaraí, Marimbus-Iraquara EPA, Marimbus do Baiano, 1-IV-2011, G.J.P. Ramos \& C.W.N. Moura s.n (HUEFS178329, HUEFS178330, HUEFS178342); 29-VI-2011, G.J.P. Ramos \& C.A. Ribeiro s.n. (HUEFS178364, HUEFS178365, HUEFS178366, HUEFS178370, HUEFS178375); Lençóis, MarimbusIraquara EPA, Marimbus do Remanso, 2-IV-2011, G.J.P. Ramos \& C.W.N. Moura s.n (HUEFS178347, HUEFS178352); 30-VI-2011, G.J.P. Ramos \& C.A. Ribeiro s.n (HUEFS178381, HUEFS178390).

Geographic distribution in Brazil: Rio Grande do Norte, Pernambuco, Distrito Federal, Minas Gerais, Espírito Santo, São Paulo, Rio de Janeiro, Rio Grande do Sul (Menezes et al. 2012) and Bahia (Fuentes et al. 2010, Santana 2011, Menezes et al. 2012).

According to Comas (1996), Monoraphidium contortum has high phenotypic plasticity. Morphologically, the taxon is similar to M. irregulare (G.M. Smith) Komárková-Legnerová; however, this species differs by having more sigmoid cells and larger cell measurements. 
The material studied agreed with the descriptions and illustrations presented by Komárek (1983), Comas (1996), Tucci et al. (2006), and Hentschke \& Torgan (2010), although the maximum cell measurements reported by the first two authors are larger than those of the specimens studied.

Thus far, the M. contortum recorded for the Bahia State has appeared only on species lists (Fuentes et al. 2010, Santana 2011, Menezes et al. 2012), where the lack of data such as descriptions and illustrations makes it difficult to study these species. Therefore, we consider the present study to be the first confirmed report of the occurrence of these species in Bahia State.

According to Komárek (1983), M. contortum is one of the most common Chlorococcales in continental water bodies. The species is cosmopolitan and is found in both plankton and periphyton, from oligotrophic to eutrophic environments (Comas 1996, John \& Tsarenko 2002).

Monoraphidium dybowskii (Woloszýnska) Hindák \& Komárková-Legnerová, Stud Phycol: 108-109. pl. $21.1969 \equiv$ Keratococcusdybowskii Wotoszýnska,Bull Int Acad Sci Cracovie, Cl Sci Math Nat Sér B:127, pl. 14, fig. 29, 1917

Figure $3 b$

Cells solitary, cylindrical, straight or slightly curved with rounded apices; parietal chloroplast without pyrenoids. Cell dimensions: $16-22.5 \mu \mathrm{m}$ in length, 3.75-6.25 $\mu \mathrm{m}$ in width.

Material examined: BRAZIL. BAHIA: Andaraí, Marimbus-Iraquara EPA, Marimbus do Baiano, 1-IV-2011, G.J.P. Ramos \& C.W.N. Moura s.n. (HUEFS178332); 29-VI-2011, G.J.P. Ramos \& C.A. Ribeiro s.n. (HUEFS178364, HUEFS178372); Lençóis, Marimbus-Iraquara EPA, Marimbus do Remanso, 30-VI-2011, G.J.P. Ramos \& C.A. Ribeiro s.n. (HUEFS 178380, HUEFS 178381 , HUEFS178394).

Geographic distribution in Brazil: Goiás (Nogueira 1999), São Paulo (Lopes 1999, Ferragut et al. 2005) and Bahia (present study).

According to Hindák (1977), Monoraphidium dybowskii is distinguished from other species in the genus by having cylindrical cells that are straight with rounded apices. Morphologically, the taxon resembles M. obtusum; however, this species differs by having larger cell dimensions and straighter apices.

The specimens studied were slightly longer than those described by Hindák (1977), Komárek \& Fott
(1983), and Komárek (1983), although they are within the metric limits reported by Nogueira (1999).

Until the 1980s, the species was known only in Central Europe (Komárek \& Fott 1983). Comas (1996) reported the taxon occurring in aquatic environments ranging from oligotrophic to Cuban mesotrophic, as a part of the plankton. In Brazil, the species was initially reported in an oligotrophic lake in the municipality of São Paulo (Lopes 1999) and in a meso-eutrophic reservoir in Goiás State (Nogueira 1999).

This report constitutes the first citation of the species for Northeastern Brazil.

Monoraphidium griffithii (Berkeley) KomárkováLegnerová Stud Phycol: 98, pl.11, fig. 1-4. 1969 三 Closterium griffithii Berkeley, Ann Mag Nat Hist Ser 2, 13: 256, pl. XIV, fig. 2. 1854.

Figure $3 \mathrm{c}$

Cells solitary, fusiform, elongated, 16-22 times longer than broad, straight or slightly curved, gradually narrowing and terminating in an acute or short spine; parietal chloroplast without pyrenoids. Cell dimensions: $45-58 \mu \mathrm{m}$ in length, $2-3.5 \mu \mathrm{m}$ in width.

Material examined: BRAZIL. BAhIA: Andaraí, Marimbus-Iraquara EPA, Marimbus do Baiano, 1-IV-2011, G.J.P. Ramos \& C.W.N. Moura s.n (HUEFS178325, HUEFS178326, HUEFS178327, HUEFS178328, HUEFS178329, HUEFS178330, HUEFS178332, HUEFS178335, HUEFS178336, HUEFS178338, HUEFS178339, HUEFS178342, HUEFS178343, HUEFS178344, HUEFS178345); 29-VI-2011, G.J.P. Ramos \& C.A. Ribeiro s.n. (HUEFS178362, HUEFS178363, HUEFS178364, HUEFS178365, HUEFS178366, HUEFS178368, HUEFS178370, HUEFS178372, HUEFS178373, HUEFS178374, HUEFS178375, HUEFS178378); Lençóis, Marimbus-Iraquara EPA, Marimbus do Remanso, 2-IV-2011, G.J.P. Ramos \& C.W.N. Moura s.n (HUEFS178347, HUEFS 178348 , HUEFS178351, HUEFS178352, HUEFS178353, HUEFS178354, HUEFS178357, HUEFS178358, HUEF S178361, HUEFS170431), 30-VI-2011, G.J.P. Ramos \& C.A. Ribeiro s.n (HUEFS178380, HUEFS178381, HUEFS178382, HUEFS178383, HUEFS178384, HUEFS178385, HUEFS178387, HUEFS178388, HUEFS178389, HUEFS178390, HUEFS178391, HUEFS178392, HUEFS178393, HUEFS178394).

Geographic distribution in Brazil: Amazonas, Rio Grande do Norte, Pernambuco, Distrito Federal, 

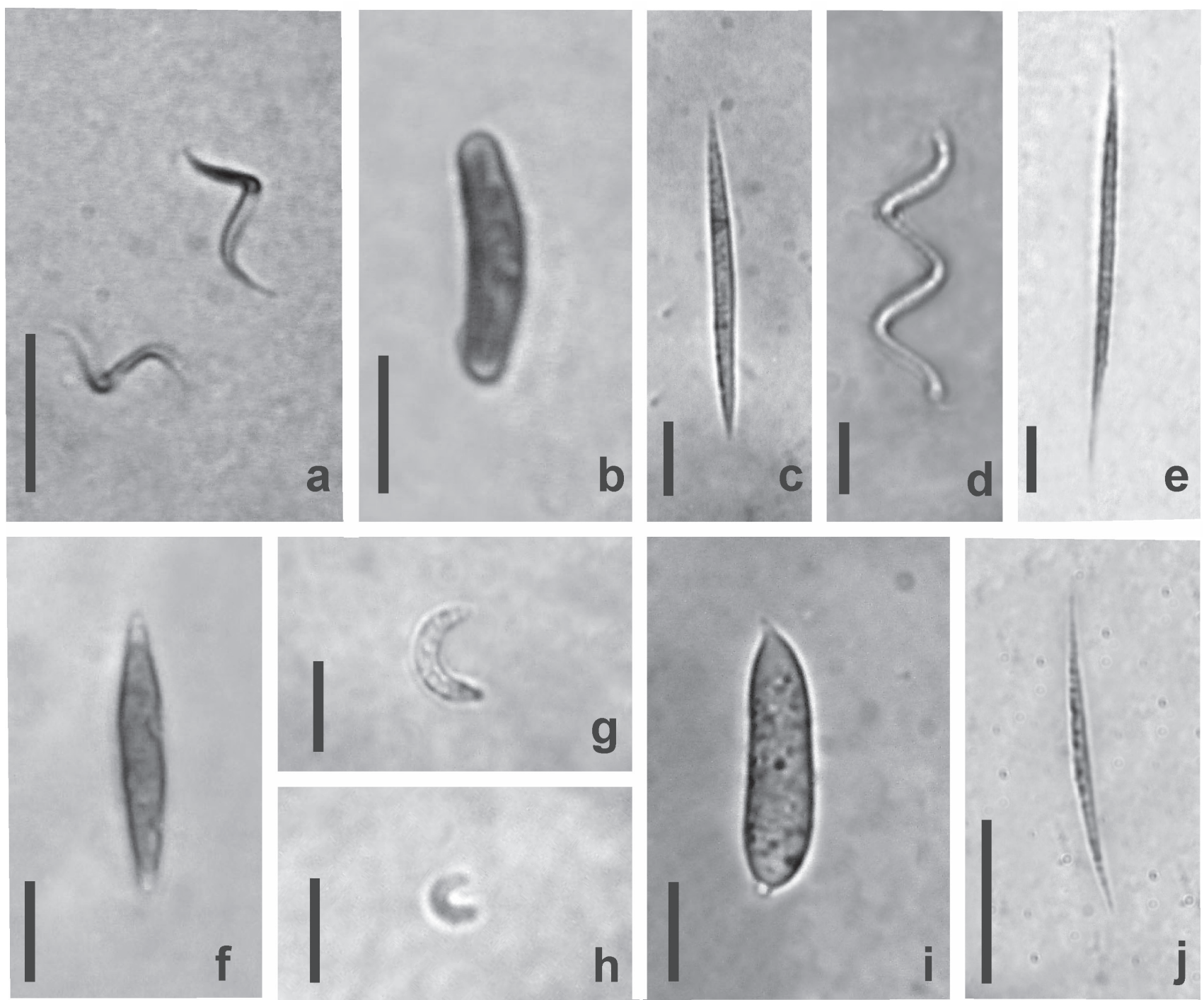

Figure 3. a. Monoraphidium contortum; b. M. dybowskii; c. M. griffithii; d. M. irregulare; e. M. kormakovae; f. M. litorale; g. M. minutum; h. M. nanum; i. M. pusillum; j. M. tortile (Bars $=10 \mu \mathrm{m})$.

Espírito Santo, São Paulo, Rio de Janeiro (Menezes et al. 2012) and Bahia (Fuentes et. al. 2010, Santana 2011).

The presence of fusiform cells that are straight with tapered apices approach Monoraphidium griffithii with $M$. komarkovae and M. tortile (W. West \& G.S. West) Komárková-Legnorová; however, $M$. komarkovae differs by having a higher length/ width ratio and more tapered and pointed apices, while M. tortile differs by having less cell dimensions.

The specimens analyzed are consistent with the descriptions and illustrations by Komárek (1983), Comas (1996), Ferragut et al. (2005), Tucci et al. (2006), and Hentschke \& Torgan (2010).

Fuentes et al. (2010) and Santana (2011) reported the occurrence of M. griffithii in Bahia State but did not provide descriptions or illustrations to allow for the restudy of these species. Therefore, we consider the present study to be the first confirmed report of the occurrence of this species in Bahia State.

According to Comas (1996), M. griffithii is likely a cosmopolitan species that is usually found in the plankton from mesotrophic and eutrophic environments.

Monoraphidium irregulare (G.M. Smith) KomárkováLegnerová, Stud Phycol:106, pl. 19. 1969 三 Dactylococcopsis irregularis G.M.Smith, Ark Bot, 17(13): 6, figs. 26-28. 1922.

Figure 3d

Cells solitary, fusiform to sigmoid, with one or two curves, sometimes cylindrical in the medial region, gradually tapered apices, pointed ends; 
single parietal chloroplast, without pyrenoids. Cell dimensions: $34-39 \mu \mathrm{m}$ in length, $1-1.5 \mu \mathrm{m}$ in width.

Material examined: BRAZIL. BAHIA: Andaraí, Marimbus-Iraquara EPA, Marimbus do Baiano, 1-IV-2011, G.J.P. Ramos \& C.W.N. Moura s.n. (HUEFS178329, HUEFS178332, HUEFS178333, HUEFS 178344); 29-VI-2011, G.J.P. Ramos \& C.A. Ribeiro s.n. (HUEFS178362, HUEFS178372); Lençóis, Marimbus-Iraquara EPA, Marimbus do Remanso, 2-IV-2011, G.J.P. Ramos \& C.W.N. Moura s.n. (HUEFS178352, HUEFS178361), 30-VI-2011, G.J.P. Ramos \& C.A. Ribeiro S.n (HUEFS178389, HUEFS178390, HUEFS178391).

Geographic distribution in Brazil: Bahia, Distrito Federal, Goiás, Minas Gerais, Paraíba, Paraná, Rio de Janeiro, Santa Catarina, São Paulo and Tocantins (Menezes et al. 2012).

The populations studied at Pantanal dos Marimbus had slightly shorter cells than those described by Komárek \& Fott (1983), Comas (1996), and John \& Tsarenko (2002), although they were within the metric limits specified by Hindák (1988) and Nogueira (1999).

The first reference to $M$. irregulare for Bahia State appears in Menezes et al. (2012), but the author did not provide a description or illustration of the material to allow for the restudy of the species. Therefore, we consider the present study to be the first confirmed report of the occurrence of this species in Bahia State.

The taxon is likely cosmopolitan and is widely distributed in the plankton from oligotrophic and mesotrophic environments (Comas 1996, John \& Tsarenko 2002).

Monoraphidium komarkovae Nygaard, Bot Tidsskr 73(3/4): 212. 1979

Figure $3 \mathrm{e}$

Cells solitary, fusiform, straight, elongated, approximately 20 times longer than broad, cylindrical in the center, gradually narrowing to long needle-like apices; parietal chloroplast and without pyrenoids. Cell dimensions: $50-105 \mu \mathrm{m}$ in length, $1.5-2.5 \mu \mathrm{m}$ in width.

Material examined: BRAZIL. BAhiA: Andaraí, Marimbus-Iraquara EPA, Marimbus do Baiano, 1-IV-2011, G.J.P. Ramos \& C.W.N. Moura s.n. (HUEFS178326, HUEFS178327, HUEFS178332, HUEFS178342), 29-VI-2011, G.J.P. Ramos \& C.A. Ribeiro s.n (HUEFS178363, HUEFS178364, HUEFS178372); Lençóis, Marimbus-Iraquara EPA,
Marimbus do Remanso, 2-IV-2011, G.J.P. Ramos \& C.W.N. Moura s.n(HUEFS178348, HUEFS178352); 30-VI-2011, G.J.P. Ramos \& C.A. Ribeiro s.n. (HUEFS178380, HUEFS178383, HUEFS178390, HUEFS178393).

Geographic distribution in Brazil: Goiás, São Paulo, Rio de Janeiro, Paraná (Menezes et al. 2012) and Bahia (Fuentes et. al. 2010, Santana 2011).

The populations from Bahia State analyzed during this study agreed with the descriptions and illustrations reported by Komárek \& Fott (1983), Nogueira (1991), and John \& Tsarenko (2002).

Fuentes et al. (2010) and Santana (2011) reported the occurrence of M. kormakovae in Bahia State from the analysis of material from the Rio de Contas and Almada River, respectively. However, the authors did not provide descriptions or illustrations of the materials that were identified, thereby preventing the restudy of the species. Therefore, we consider the present study to be the first confirmed report of the occurrence of this species in Bahia State.

Monoraphidium litorale Hindák, Biol Prace 30 (1): 228, pl. 80, fig. 1. 1984.

Figure $3 \mathrm{f}$

Cells solitary, fusiform, straight, gradually tapered apices, pointed ends; single parietal chloroplast without pyrenoids. Cell dimensions: $22.5-28 \mu \mathrm{m}$ in length, 2.5-3.5 $\mu \mathrm{m}$ in width.

Material examined: BRAZIL. BAHIA: Andaraí, Marimbus-Iraquara EPA, Marimbus do Baiano, 29-VI-2011, G.J.P. Ramos \& C.A. Ribeiro s.n (HUEFS178372); Lençóis, Marimbus-Iraquara EPA, Marimbus do Remanso, 30-VI-2011, G.J.P. Ramos \& C.A. Ribeiro s.n (HUEFS178387, HUEFS178389). Geographic distribution in Brazil: Goiás (Nogueira 1999) and Bahia (present study).

Monoraphidium litorale is morphologically close to M. pusillum (Printz) Komárková-Legnerová and $M$. affixum Hindák, differing from the first by having less tapered apices and generally longer cells and differing from the second by having smaller and straighter cells.

The populations of $M$. litorale analyzed in this study agreed with the descriptions and illustrations reported by Hindák (1984) and John \& Tsarenko (2002).

The first record of this species for Brazil appears in Nogueira (1999) from material collected in a Samambaia reservoir, located at the Universidade Federal de 
Goiás (UFG), Goiás State, but the cell dimensions presented by this author are smaller than those found in the specimens from the Pantanal dos Marimbus.

This report constitutes the first citation of the species for Northeastern Brazil.

Monoraphidium minutum (Nägeli) KomárkováLegnerová, Stud Phycol:109. $1969 \equiv$ Rhaphidium minutum Nägeli, Gatt Einzell Alg, p.83, pl. IV: C, fig. 2. 1849 .

Figure $3 \mathrm{~g}$

Cells solitary, lunate or reniform, in the same plane, to the ends rounded; single parietal chloroplast without pyrenoids. Cell dimensions: 9-12 $\mu \mathrm{m}$ in length, $2.5-3 \mu \mathrm{m}$ in width.

Material examined: BRAZIL. BAHIA: Lençóis, Marimbus-Iraquara EPA, Marimbus do Remanso, 30-VI-2011, G.J.P. Ramos \& C.A. Ribeiro s.n. (HUEFS178389, HUEFS178393).

Geographic distribution in Brazil: Amazonas, Distrito Federal, Espírito Santo, Paraná, Rio de Janeiro, and São Paulo (Menezes et al. 2012), and Bahia (Menezes et al. 2012, Santana 2011).

According to its morphological features, Monoraphidium minutum is close to M. nanum (Ettl) Hindák; however, this species is distinguished by having smaller cell dimensions and cells with a smaller degree of curvature. It is similar to the solitary cells of Kirchneriella Schmidle but differs by having cells surrounded by a sheath of mucilage.

The populations studied were slightly larger than those described by Komárek (1983) and Comas (1996), although they are within the metric limits referred to by Komárek \& Fott (1983), Nogueira (1999), and John \& Tsarenko (2002).

Menezes et al. (2012) and Santana (2011) reported the occurrence of M. minutum in Bahia State; however, the authors did not present descriptions or illustrations of the material to allow us to compare them to the specimens studied here. Therefore, we consider the present study to be the first confirmed report of the occurrence of this species in Bahia State.

According to Comas (1996), this species is cosmopolitan and is frequently found in tropical environments, inhabiting both plankton and periphyton from alkaline water bodies.

Monoraphidium nanum (Ettl) Hindák, Biol Prace, 26(6):145, pl. 59, figs. 2-4. 1980 $\equiv$ Nephrodiella nana Ettl, Nova Hedwigia 28: 559. 1977

Figure $3 \mathrm{~h}$
Cells solitary, lunate or reniform, to the ends rounded, parietal chloroplast without pyrenoids. Cell dimensions: 4-6 $\mu \mathrm{m}$ in length, 2.5-3.5 $\mu \mathrm{m}$ in width.

Material examined: BRAZIL. BAhia: Andaraí, Marimbus-Iraquara EPA, Marimbus do Baiano, 1-IV-2011, G.J.P. Ramos \& C.W.N. Moura s.n (HUEFS178329, HUEFS178332, HUEFS178333, HUEFS178341); Lençóis, Marimbus-Iraquara EPA, Marimbus do Remanso, 2-IV-2011, G.J.P. Ramos \& C.W.N. Moura s.n. (HUEFS178352, HUEFS178354), 30-VI-2011, G.J.P. Ramos \& C.A. Ribeiro s.n. (HUEFS178390).

Geographic distribution in Brazil: Amazonas, Bahia, Espírito Santo, Goiás, Rio de Janeiro, Santa Catarina and São Paulo (Menezes et al. 2012).

Hindák (1988) described the phenotypic plasticity in M. nanum, varying from reniform to oblong or ovate.

The specimens studied in the Pantanal dos Marimbus agrees with the descriptions and illustrations of individuals analyzed by Komárek \& Fott (1983), Nogueira (1999), and Tucci et al. (2006).

Monoraphidium pusillum (Printz) KomárkováLegnorová, Stud Phycol:102-103, pl. 16. 1969. Figure 3i

Cells solitary, fusiform, straight to slightly curved, generally very broad in the medial region; tapered to finger-like apices; parietal chloroplast without pyrenoids. Cell dimensions: $25-28.5 \mu \mathrm{m}$ in length, 5-7.5 $\mu \mathrm{m}$ in width.

Material examined: BRAZIL. BAHIA: Lençóis, Marimbus-Iraquara EPA, Marimbus do Remanso, 30-VI-2011, G.J.P. Ramos \& C.A. Ribeiro s.n. (HUEFS170417, HUEFS170421).

Geographic distribution in Brazil: Bahia, Goiás, Paraná, Pernambuco, Rio de Janeiro, and São Paulo (Menezes et al. 2012).

The specimens studied had slightly larger cell than those described by Komárek \& Fott (1983) and Comas (1996).

The first reference to M. pusillum in Bahia State is in Menezes et al. (2012), but the authors did not provide description or illustration of the material that would allow us to restudy the taxon. Therefore, we consider the present study to be the first confirmed report of the occurrence of these species in Bahia State.

The species is likely cosmopolitan and is usually found in the plankton from oligotrophic to mesotrophic aquatic environments (Comas 1996, John \& Tsarenko 2002). 
Monoraphidium tortile (W. West \& G.S. West) Komárková-Legnorová, Stud Phycol, p.102-103. $1969 \equiv$ Ankistrodesmus tortilis W. West \& G.S. West, J Linn Soc Bot 40: 431. 1912.

Figure $3 \mathrm{j}$

Cells solitary, fusiform, straight or slightly curved, tapered apices; single parietal chloroplast without pyrenoids. Cell dimensions: $12-20 \mu \mathrm{m}$ in length, $1.5-2.5 \mu \mathrm{m}$ in width.

Material examined: BRAZIL. BAHIA: Andaraí, EPA Marimbus-Iraquara, Marimbus do Baiano, 29-VI-2011, G.J.P. Ramos \& C.A. Ribeiro s.n. (HUEFS178372); Lençóis, EPA Marimbus-Iraquara, Marimbus do Remanso, 30-VI-2011, G.J.P. Ramos \& C.A. Ribeiro s.n (HUEFS178381).

Geographic distribution in Brazil: Amazonas, Tocantins, Mato Grosso, Distrito Federal, São Paulo, Rio de Janeiro, Paraná (Menezes et al. 2012) and Bahia (present study).

Komárek \& Fott (1983) considered $M$. pseudobraunii (J.H. Belcher \& Swale) Heynig to be synonymous to $M$. tortile, although Hindák (1984) recognizes the two species to be separate.

The populations from Bahia State that were analyzed in this study agreed with the descriptions and illustrations by Komárek \& Fott (1983), John \& Tsarenko (2002), and Ferragut et al. (2005).

This report constitutes the first citation of the species for Northeastern Brazil.

The taxonomic inventory conducted at the two areas of the Pantanal dos Marimbus (Baiano and Remanso) recorded the occurrence of 18 taxa, 13 of Monoraphidium and five of Ankistrodesmus.

Of the total taxa studied, eight are cited for the first time in Northeastern Brazil: Ankistrodesmus bernardii, A. densus, A. falcatus, Monoraphidium caribeum, M. circinale, M. dybowskii, M. litorale, and M. tortile, as well as Ankistrodesmus spiralis is an addition to continental microalgae flora of Bahia State.

During the analysis of the Monoraphidium genus, the main difficulty to identifying certain species (M. arcuatum and $M$. caribeum) was related to the degree of curvature of the cells, which was sometimes more or less open. In addition, taxa with typically straight cells, such as M. griffthii, sometimes had slightly curved cells. In Ankistrodesmus, the main difficulty in separating the colonies into different groups was in delimiting the taxa because the single cells are usually confused with individuals of Monoraphidium, i.e., cells of $A$. spiralis that are similar to $M$. irregulare. However, in both cases, studying the populations was essential for differentiating between the taxa.

The number of species of Monoraphidium identified in the present study was higher when compared with the studies of Ferragut et al. (2005) and Tucci et al. (2006), which cited seven and eight taxa respectively, in the shallow oligotrophic reservoir (lake at IAG) and in the Lago das Garças, both in São Paulo State; Bortolini et al. (2010), who recorded three taxa in the Embrapa Gado de Corte in Mato Grosso do Sul State; and Hentschke \& Torgan (2010), who reported four taxa at the Butiazal de Tapes and Lagoa do Casamento in Rio Grande do Sul State.

Monoraphidium dybowskii, reported by Nogueira (1999) and Ferragut et al. (2005), and M. litorale reported by Nogueira (1999), which are all rare in Brazil, were collected in this study.

Comparing the occurrence of species at the two areas in the Pantanal dos Marimbus (Baiano and Remanso), we found that almost all of the taxa were common between the two areas, except for Ankistrodesmus bernardii, which occurred only at Baiano, and Monoraphidium minutum, which only occurred at Remanso. The most representative species in the study area were Monoraphidium griffithii and Ankistrodesmus densus.

This study has expanded the knowledge of the biodiversity of the Ankistrodesmus and Monoraphidium in Bahia State and extends the geographic distribution of these in Northeastern Brazil. Based on the results obtained, the number of taxa recorded for Bahia of the Ankistrodesmus increased from three to five taxa and Monoraphidium from eight to thirteen.

\section{Acknowledgements}

We would like to thank the Coordenação de Aperfeiçoamento de Pessoal do Ensino Superior (CAPES) for granting the master scholarship to the first author, the Universidade Estadual de Feira de Santana - UEFS for logistic support, and the Projeto Ecológico de Longa Duração - PELD - Chapada Diamantina for the financial support that makes sample collection possible.

\section{Literature cited}

Bicudo, C.E.M. \& Menezes, M. 2006. Gêneros de algas de águas continentais do Brasil: chave para identificação e descrições. 2 ed. Rima, São Carlos. 
Bortolini J.C., Biolo S., Bueno N.C., Godinho L.R. \& Pott V.J. 2010. Chlorococcales sensu lato (Chlorophyceae) em tanques de depuração de efluente de origem bovina no Mato Grosso do Sul, Brasil. Iheringia 65: 63-74.

Comas, G.A. 1996. Las Chlorococcales dulciacuícolas de Cuba. Bibliotheca Phycologica, J. Cramer, Berlin.

De-Lamonica-Freire, E.M. \& Heckman, C.W. 1996. The seasonal succession of biotic communities in wetlands of the tropical wet-and-dray climatic zone: III. The algal communitiesin the Pantanal of Mato Grosso, Brazil, with a comprehensive list of the known species and revision of two desmid taxa. Internationale Revue der gesamten Hydrobiologie und Hydrographie 81: 253-280.

De-Lamonica-Freire, E.M. \& Sant'Anna C.L. 1993. Chlorococcales Chlorophyceae da Estação Ecológica da Ilha de Taiamã, Estado de Mato Grosso, Brasil. Hoehnea 20: 107-118.

El-Sheekh M.M., El-Naggar A.H., Osman Meh \& ElMazaly, E. 2003. Efeito do cobalto no crescimento, pigmentos e transporte de elétrons na fotossíntese em Monoraphidium minutum e Nitzchia perminuta. Brazilian Journal of Plant Physiology 15: 159-166.

Ferragut, C., Lopes, M.R.M., Bicudo D.C., Bicudo, C.E.M. \& Vercellino I.S. 2005. Ficoflórula perifítica e planctônica (exceto Bacillariophyceae) de um reservatório oligotrófico raso (Lago do IAG, São Paulo). Hoehnea 32: 137-184.

França, F., Melo E., Oliveira, I.B., Reis, A.T.C.C.R., Alves, G.L. \& Costa, M.F. 2011. Plantas vasculares das áreas alagadas dos Marimbus, Chapada Diamantina, BA, Brasil. Hoehnea 37: 445-460.

Fuentes, E.V., Oliveira, H.S.B., Cordeiro-Araújo M.K., Severi W. \& Moura, A.N. 2010. Variação espacial e temporal do fitoplâncton do Rio de Contas, Bahia, Brasil. Revista Brasileira de Engenharia de Pesca 5: 13-25.

Hentschke, G.S. \& Torgan L.C. 2010. Chlorococcales lato sensu (Chlorophyceae, excl. Desmodesmus e Scenedesmus) em ambientes aquáticos na Planicie Costeira do Rio Grande do Sul, Brasil. Iheringia 65: 87-100.

Hindák F. 1977. Studies on the Chlorococcal algae (Chlorophyceae). I. Biologické Práce 23. Veda, Bratislava.

Hindák F. 1984. Studies on the Chlorococcal algae Chlorophyceae. III, Biologické Práce, 30. Veda, Bratislava.

Hindák F. 1988. Studies on the Chlorococcal algae (Chlorophyceae). IV. Biologické Práce, 34. Veda, Bratislava.

John, D.M. \& Tsarenko, P.M. 2002. Order Chlorococcales. In: D.M. John, B.A. Whitton \& A.J. Brook (eds.). The Freshwater Algal Flora of the British Isles. An identification guide to freshwater and terrestrial algae. Cambridge University Press, New York, Cambridge, pp. 327-409.
Komárek, J. \& Fott, B. 1983. Das Phytoplankton des Süsswassers: Systematic und Biologie. E. Schweizerbart'sche Verlagsbuch - handling Nägele u. Obermiller

Lopes, M.R.M. 1999. Eventos perturbatórios que afetam a biomassa, a composição e a diversidade de espécies do fitoplâncton em um lago tropical oligotrófico raso (Lago do Instituto Astronômico e Geofísico, São Paulo, SP). Tese de Doutorado, Universidade de São Paulo, São Paulo.

Komárek, J. 1983. Contribution to the Chlorococcal Algae of Cuba. Nova Hedwigia 37: 65-180.

Menezes, M., Branco, C.Z., Peres, C.K., Fajar, A., Tucci, A. \& Nogueira, I. 2012. Chlorophyceae. In: Lista de Espécies da Flora do Brasil. Jardim Botânico do Rio de Janeiro. http://floradobrasil.jbrj.gov.br/2012/FB118453 (accesso em 09.02.2012).

Nogueira, I.S. \& Oliveira, J.E. 2009. Chlorococcales e Ulothricales de hábito colonial de quatro lagos artificiais do município de Goiânia - GO. Iheringia 64: 123-143.

Nogueira, I.S. 1991. Chlorococcales sensu lato Chlorophyceae do Município do Rio de Janeiro e arredores, Brasil: inventário e considerações taxonômicas. Dissertação de Mestrado, Universidade Federal do Rio de Janeiro, Rio de Janeiro.

Nogueira, I.S. 1999. Estrutura e dinâmica da comunidade fitoplanctônica da represa Samambaia, Goiás, Brasil. Tese de Doutorado, Universidade de São Paulo, São Paulo.

Reynolds, C.S. 1984. Ecology of freshwater phytoplankton. Cambridge University Press, New York.

Sant'Anna C.L. 1984. Chlorococcales Chlorophyceae do Estado de São Paulo, Brasil. J Cramer. Bibliotheca Phycologica, Berlin.

Santana, L. M. 2011. Análise física e química da água e estrutura da comunidade fitoplanctônica do Rio Almada Sul da Bahia. Dissertação de Mestrado, Universidade Estadual de Santa Cruz, Ilhéus.

SEMA - Secretaria do Meio Ambiente - Governo do Estado da Bahia. http://www.semarh.ba.gov.br/ conteudo.aspx?s=APAMARIM\&p=APAAPA (acesso em 16.06.2011).

Sipaúba-Tavares, L.H., Pelicioni L.C. \& Oliveira A. 1999. Use of inorganic NPK and the CHU12 medium for cultivation of Ankistrodesmus gracilis in laboratory. Brazilian Journal of Ecology 1: 10-15.

Taniguchi, G.M., Bicudo, D.C. \& Senna, P.A.C. 2005. Gradiente litorâneo-limnético do fitoplâncton e ficoperifíton em uma lagoa da planície de inundação do Rio Mogi-Guaçu. Revista Brasileira de Botânica 28: 137-147.

Tucci, A., Sant'Anna C.L., Gentil, R.C. \& Azevedo, M.T.P. 2006. Fitoplâncton do Lago das Garças, São Paulo, Brasil: um reservatório urbano eutrófico. Hoehnea 33: 147-175. 